\title{
Development of Learning Everywhere Class (LEKAS) Platform for Economic Education
}

\author{
https://doi.org/10.3991/ijim.v15i09.21585 \\ Rizza Megasari ${ }^{(凶)}$, Agung Haryono, Rizky Dwi Putri, Lisa Rokhmani, \\ Ro'ufah Inayati, Sri Handayani, Annisya' \\ Universitas Negeri Malang, Malang, Indonesia \\ rizza.megasari.fe@um.ac.id
}

\begin{abstract}
The main objective of this research is to develop an Androidbased mobile learning platform for economic education students so that they can study anywhere and anytime. Following the current trend, learning must be flexible in accordance with learning styles that tend to lead to online learning. Students will be more comfortable studying with their smartphones anywhere than having to carry books everywhere. This platform consists of several features, namely lecture material, evaluation results and progress of reading material in the form of PDF and video embedding. The design development in this study uses the ADDIE model, which consists of 5 stages, namely Analysis, Design, Development, Implementation, and Evaluation. This product was tested on 60 students of economic education class 2019 in introduction of macroeconomics courses. The final product of this research is an Android-based mobile learning platform with the title LEKAS (Learning Everywhere Class). The results of the evaluation of this product are that there is still a need for improvements in the ease of access to various types of android. The advantage is that students can immediately learn and find out the extent of understanding by taking tests after studying the material that has been shared. Through this platform students can study material and evaluate the material they read anywhere and anytime. The convenience provided on this platform will be able to increase the effectiveness and efficiency of learning in economic education.
\end{abstract}

Keywords-Android-based, Learning Platform, Economic Education, ADDIE model, Learning Everywhere Class (LEKAS)

\section{$1 \quad$ Introduction}

Learning activities are very dynamic activities where teachers are required to have innovation and creativity in delivering material so that learning activities are not monotonous and make students' learning motivation decrease [1]. A teacher's innovation and creativity can be enhanced by using learning models and media that are in accordance with the characteristics of the material to be delivered. Economic material has different characteristics from other social materials. Economic material contains facts, events, concepts, laws and procedures that must be understood by students. In delivering the teaching material, of course, it must have a reference, namely the learn- 
ing objectives that must be achieved in accordance with the applicable curriculum in each university. The delivery of material in the economic education study program so far still uses the lecture and discussion method in its learning activities. This method is still far behind the current conditions in the Industrial Revolution 4.0 which prioritizes technology in every field, including in the field of education [2]. Due to its ubiquitous expansion and ease of use, the network provides quick access to various areas of interest [3]. Mobile learning increases students' interest and motivation in learning activities [4]. In addition, mobile learning is able to make a pedagogical shift from class-based learning to collaborative and constructivist learning [5].

The development technology allows each person in different ways, which should be used for things that are useful. One of these benefits can be used to facilitate a student in increasing motivation and interest in learning. Learning resources are no longer only from printed books in the library and also information provided by teachers. Students can take advantage of various learning resources available around them. In the world of education today, various platforms are used to support learning, making it easier for students to master teaching material with or without teacher intervention [1]. The face-to-face learning process involving students and teachers in the class is considered less effective and efficient again, because it is limited to scheduled space and time so that students are not maximal in mastering the material taught by the teacher in the classroom and students when they do not understand cannot repeat the same material delivered by the teacher. So that the implementation of classical learning activities is still not used effectively until now. In addition, teachers cannot control students in their learning activities outside the classroom. As stated in [6] the lack of communication and interaction between teachers and students is one of the main challenges for implementing learning. Only by taking advantage of the limited face-to-face meeting time, teachers often pursue material content without paying attention to the boredom that plagues students. So that when face-to-face meetings in class, it is not uncommon for students to find students enjoying playing their smartphones with social media or playing games to reduce boredom when learning in class.

At present, the world has entered the era of the 4.0 industrial revolution where technological developments and sophistication have greatly influenced human life, where everything seems to be limitless space and time due to the development of the internet and digital technology. However, the concept of digitizing education still moves the teaching system from conventional to digital format [7]. The presence of the industrial revolution era 4.0 provides a new color in the world of education. The role of technology in education is undeniable, where currently the Government has regulated the need for technology in various laws and regulations. As stated in [8] that "the use of technology is expected to increase student interest in learning because the conventional learning process is deemed unpleasant and monotonous". Learning that prioritizes teacher activities and textbooks will make students feel bored and bored with learning in class. Therefore, a learning innovation is needed, one of which is learning based on information and communication technology so that it is expected to make students more enthusiastic about learning. 
The rapid advancement of technology has resulted in increasingly diverse types and forms of learning sources, as well as the nature of good learning resources, which must be flexible and adapt to where the learning resources are located. Learning sources can also be said to be all sources that contain knowledge and information that can be packaged through computers, cellphones, the internet and others [9]. One of the innovative learning strategies that can be implemented with current trends is to carry out learning anytime and anywhere according to the needs and desires of students in understanding the material [10].

[11] Classifies learning resources into six types, namely; messages, people, materials, tools, techniques and settings. The six types of learning resources contain a core, namely the message to be conveyed to students. Learning resources in the form of applications are sources of learning types of materials. Materials as learning resources include print / non-print media that contain information and can help students achieve their learning goals [12] Materials are also often referred to as software or software.

As stated in [13] " Android is a software (software) that is used on a mobile device (running device) which includes the operating system, middleware and core applications". Android according to [8] is an operating system for smartphones and tablets. The operating system can be illustrated as a bridge between a device and its use, so that users can interact with the device and run applications available on the device. Another reference is found that [14] argues that Android is a Linux-based operating system specifically for mobile devices such as smartphones or tablets. This Android operating system is open source, so a lot of programmer's flock to make applications or modify this system. Programmers have a very big opportunity to be involved in developing Android applications for this opensource reason. Most of the applications on the Play Store are free and some are paid. This also motivates teachers to facilitate student learning preferences by using android as a learning resource for students. The current appropriate teaching method is that students freely use technology to learn and read material repeatedly according to their learning rhythm [15].

Based on the above opinion, one of the alternative learning media that can be offered to students is mobile -based learning. This learning media is considered to be able to support the learning process in the economic education study program. The need for innovation in the development of alternative learning systems that are attractive and interactive in their use. Developing mobile learning for economic education principled paperless and everywhere every time learning. In connection with the need for innovation, it is necessary to develop a learning alternative in the form of the development of a LEKAS (learning everywhere class) platform for economic education. The formulation of the problem in this study is how to design mobile learning using android for economic education. While the goal in this study is to describe the design of mobile learning to use Android for Education in the economy.

\section{Relevant Literature}

There is no specific definition to explain mobile learning, but there are four dimensions to explain the purpose of this mobility including technology mobility, student 
mobility, educator mobility and learning mobility [16]. Mobile learning was originally defined as the technology used in learning. Or in other words, mobile learning is defined as the provision of learning through a set of handheld devices, this means that it can be a cell phone, smartphone, tab, tablet or palmtop computer - a handheld computer, PDA, but not a PC with a large desktop that is not easy to carry [17]. This explains the type and technology used. Along with the development of technology that can be used in learning both hardware, software, and various file formats, this definition becomes unstable and its clarity is questionable [18]. This understanding then develops in the mobility of students, educators and learning where the community is able to convey learning to individuals, groups, communities and countries that were previously socially and geographically restricted. Another current definition explains that mobile learning is able to enrich and enhance learning activities from previous abilities. This is certainly not the end of the development of the definition of mobile learning. Along with the rapid development of science and technology, the need for learning, the pedagogic competence of educators, the shortcomings of previous mobile learning and the budgetary problems they have will continue to be the basis for the rapid development of the definition of this mobile learning.

There is a difference between e-learning and mobile learning. Based on the definition, it is known that mobile learning is learning by utilizing a variety of features and handheld devices, while e-learning makes use of larger devices such as computers with networks. E-learning also has characteristics that are able to present learning massively, can be accessed by network, equipped with various features of structured and interactive learning media. Meanwhile, according to its definition, mobile learning has the characteristics of automatic, instant, portable, personal, informal, small, lightweight [17] and even now it has been connected, customized and interactive. This limitation of use in mobile learning can be an obstacle to learning modes that require content explanation. Meanwhile, the limited connectivity will be a problem for practical materials or courses or interviews and synchronous delivery of material [17]. In other words, the seemingly technical characteristics that differentiate one set of devices from another can be a hindrance as it tends to match the set of tools being developed and used. Therefore, educators need to explore learning models, methods and tools to present fun and engaging mobile-based learning.

Online-based learning using smartphones is also known as mobile learning. This mobile learning explains the role of the new technology being developed to be able to provide a forum for knowledge management, accessibility and delivery and acceptance of material delivered with a design that is suitable for the characteristics of students and learning materials [16][19]. The use of smartphones to support learning activities is very popular and in demand by students at various age levels, both children [20] to students [21][22], applicable and effective in improving learning outcomes [23][24] including social science students [25]. This is also evidenced by the data released by APJII which explains that internet penetration in Indonesia with a sample of population aged more than 15 years has increased to reach $73.7 \%$ of the population where $95.4 \%$ access the internet from smartphones [26].

Aspects that encourage the growth of online-based learning include the need for distance learning that is easy, comfortable and effective to use anywhere, anytime and 
by anyone without being limited by gender and age [19][27] as well as wide open access both in formal and informal education [28] especially in the current pandemic era, where online learning is required.

Even though mobile learning is very suitable for millennial students because they are very close to gadgets in everyday life, one of the main things that cannot be forgotten is knowing the needs and readiness of students and educators in mobile learning [29]. To get optimal learning outcomes, careful preparation is needed in each element of mobile learning according to the learning environment. Some of the features that are very helpful in mobile learning include reminders, free settings for profiles, progress reports and download options for offline access that can allow students to be able to study material in minimal conditions even without a network [23][27] . The limitations faced by online learning are constraints on network access, the absence of gadgets, operational capabilities and limited physical interaction between students and educators [28]. Another challenge faced by mobile learning implementers and developers is balancing internal interests, related to the development of work, and external interests related to the context and the urgency of this development [18]. Therefore, every good in the results of mobile learning development will seem subjective in accordance with the problems that each product wants to solve, with the advantages that are expected to cover any shortcomings of other similar applications, the urgency of product development can be implemented and helps in problem solving, especially in learning [30].

\section{$3 \quad$ Research Method}

This research is a development research. The product produced from this study is an Android-based platform with the title LEKAS (Learning Everywhere Class). The development design that will be used in this research is ADDIE. The researcher describes the ADDIE development design stages as follows: 


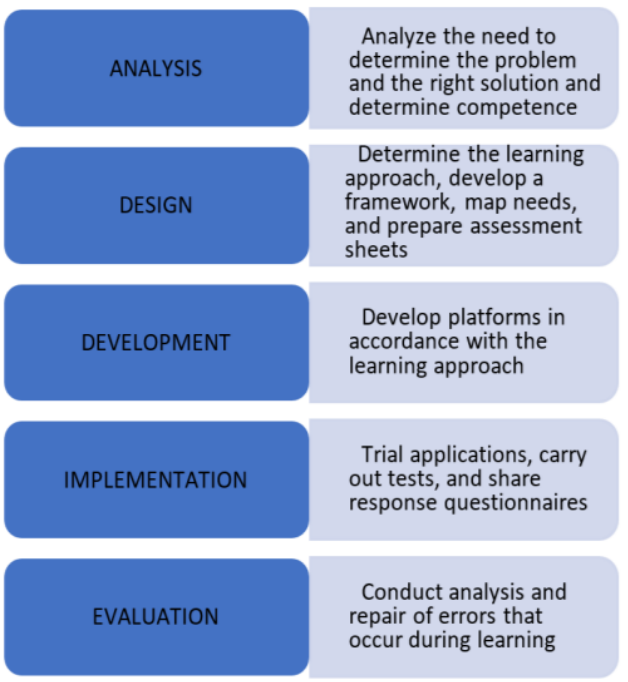

Fig. 1. Steps for developing the LEKAS platform

The following is an explanation of the ADDIE development stage that the researchers will do.

\section{Analysis}

The analysis stage is the stage where the researcher analyzes the need for the development of teaching materials and analyzes the feasibility and development requirements. The stages of analysis carried out by the author include three things, namely needs analysis, curriculum analysis, and character analysis of students. to formulate indicators of learning achievement. The analysis was carried out through interviews with students regarding what problems were faced during the teaching and learning process which consisted of

a. Motivation to learn

b. Interest to learn

c. Learning outcomes

d. Critical thinking

e. The use of technology in learning

f. Learning models and methods

g. Interaction and communication between teachers and students.

The curriculum used in the economic education study program at Universitas Negeri Malang is life-based KKNI. Students are intended for generation Z who have characteristics with high and realistic mobility. The majority of Generation $Z$ have an interest in social networks and a high understanding of digital. Students of 2019 class became research subjects in the subject of Introduction of Macroeconomics Offering $\mathrm{BB}$ and $\mathrm{A}$, totaling 60 students. 


\section{Design (Design)}

The second stage of the ADDIE model is the design stage. At this stage, a platform is designed to be developed according to the results of the previous analysis. At this stage, developers and researchers discuss the LEKAS mobile learning design which is adjusted to the analysis in the first stage.

\section{Development}

The development stage is the product realization stage. At this stage the development of the platform is carried out according to the design by the developer and then the results of the design are discussed roughly. After that, the platform will be validated by expert lecturers. After the validation process, there will be a process of fixing features that are still not suitable and adding necessary features. The researcher entered the material and also the evaluation on the LEKAS platform to then be implemented.

\section{Implementation (Implementation)}

The fourth stage is implementation. Implementation is limited to students who are designated as research sites. The designated students are students of class 2018. Students install the LEKAS platform on their smartphones. Register then enter on the platform according to the subject. Then study the material that has been input by the researcher. After the learning process is complete, students take tests using the questions provided by the researcher to measure the achievement of learning objectives.

\section{Evaluation}

At this stage, the researcher made the final revision of the platform developed based on input obtained from the response questionnaire or field notes on the observation sheet. It is intended that the platform developed is truly suitable and can be used by a wider range of students.

The data obtained from the assessment of material experts, instructional media experts, and from potential product users are qualitative and quantitative. Quantitative data were obtained from questionnaires while qualitative data were based on suggestions, input and comments from the assessment of trial experts and product users.

\section{$4 \quad$ Results and Discussion}

\subsection{System interface}

The development of Android-based mobile learning as a learning medium can be used as a solution to overcome learning problems, both in terms of limited time, media $\&$ broadcasting, and learning methods [31]. The use of Android-based mobile learning media using LEKAS can run well and effectively so that it has an influence on increasing student motivation and interest in learning. This early product 
developed using instructional media applications in the form of development of software.

This application model uses a thumb focused interaction model. This model aims to make this application run using one hand without difficulty. This application is installed on an Android smartphone only so that if students have an IOS-based smartphone they cannot use this platform to learn.

The flow chart design of this application is as follows:

\section{Desain Flowchart Aplikasi}

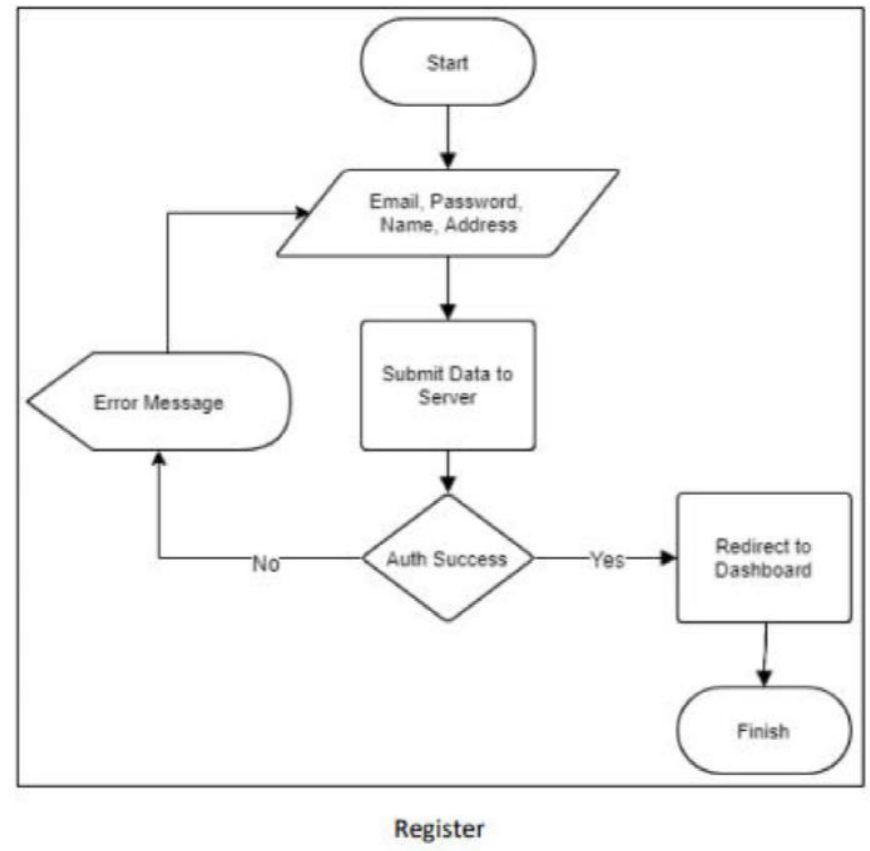

Fig. 2. Application Registration Page

The image above shows the system on the dashboard where participants can choose what menu they need in the LEKAS application. The feature in LEKAS is home, the material is by selecting the courses to be taken and then entering the material in the form of a PDF file or learning video. There are evaluation results as well as a feature of measuring learning objectives. And there is also a student profile feature. 


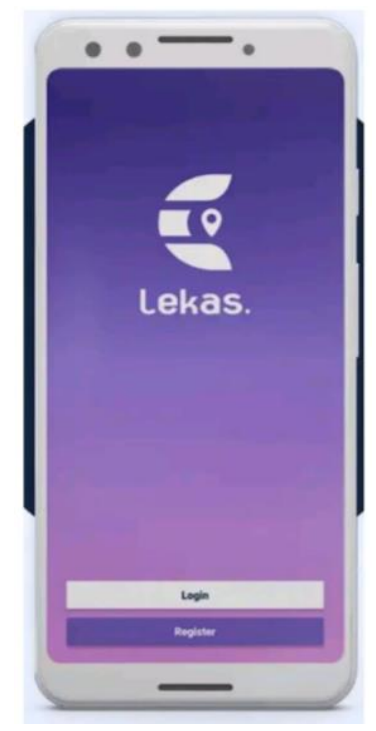

Fig. 3. Display the LEKAS Login page
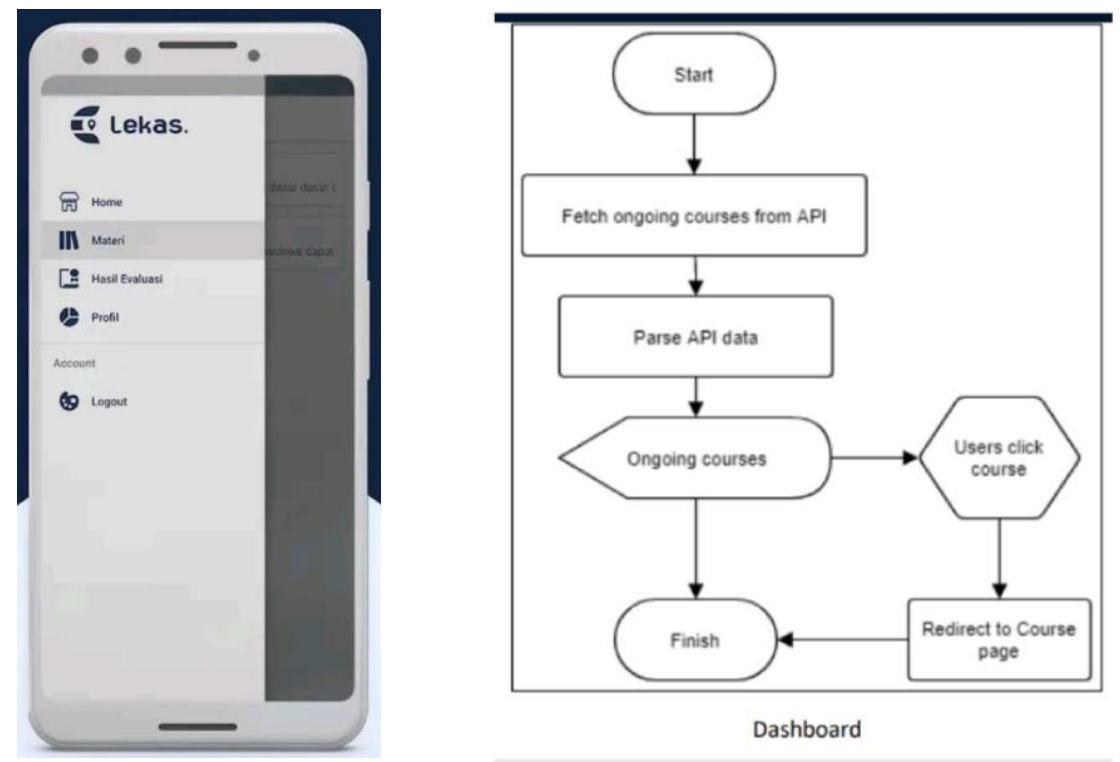

Fig. 4. A Process on the dashboard

The image above is a display image on the LEKAS dashboard. Participants can choose the material menu to be viewed for study, an evaluation to be carried out, update their personal profile, or the logout menu to exit the application. 


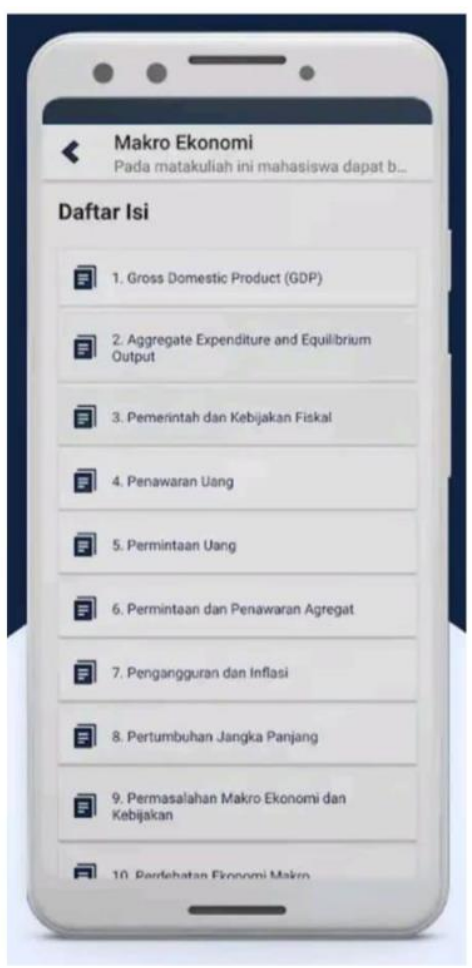

\section{용 \\ $\equiv$ Materi}

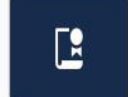

Matematika Diskrit

Matematika

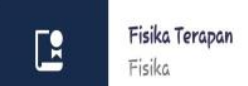

[9. Bahasa Inggris Teknik

[E. Dasar Pemrograman

Belajar bahasa pemrograman C++d

$[9$

Pengantar Ekonomi Makro

matakuliah ini membahas mengenai

$[9$

Pengantar Ekonomi Mikro

matakuliah ini membahas mengenai

Fig. 5. Display on the course menu

The image above describes the flow on the course menu. In this part of the course menu, participants can choose the course menu that will be followed by participants. After selecting the existing course menu, participants will be taken to the course content menu. On this menu, participants can choose what material to study on this course. The following is a display on the material menu provided by the teacher. The next picture is a picture of material evaluation. 


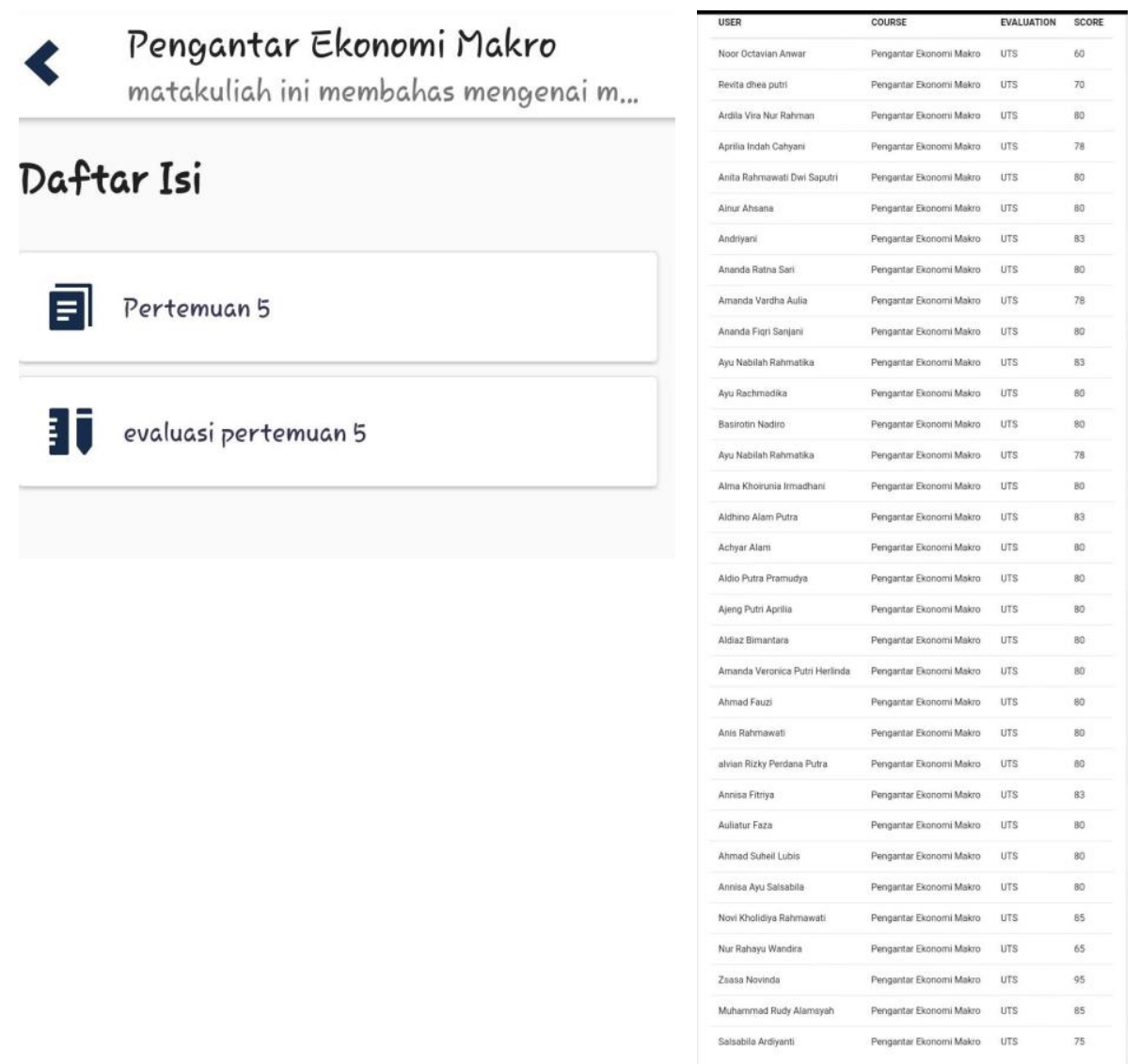

Fig. 6. Course Evaluation

The picture above explains the flow of the course evaluation that will be used by the participants to carry out learning evaluation activities on the courses they are participating in. Participants can choose what type of evaluation to use. There are 2 types of evaluation that can be used, namely multiple choice and essay. Students by participating in the evaluation can measure their ability to understand and master the material. Students can repeatedly do evaluations until they get the maximum score. The average score obtained by students after doing the evaluation is in the range $60-95$. The questions that are done are multiple choice with a total of 25 questions. 


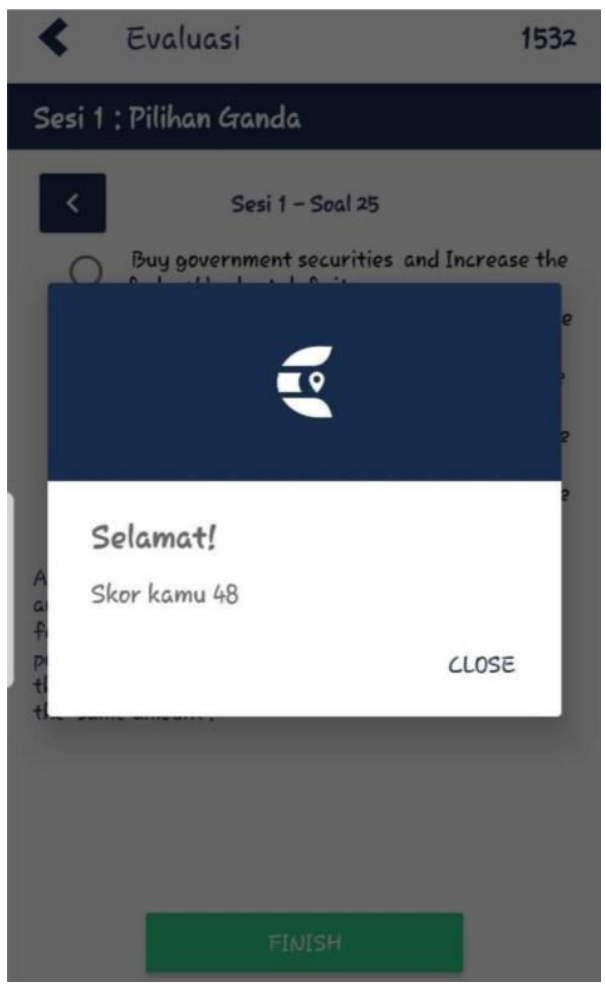

Fig. 7. Assessment

Asest

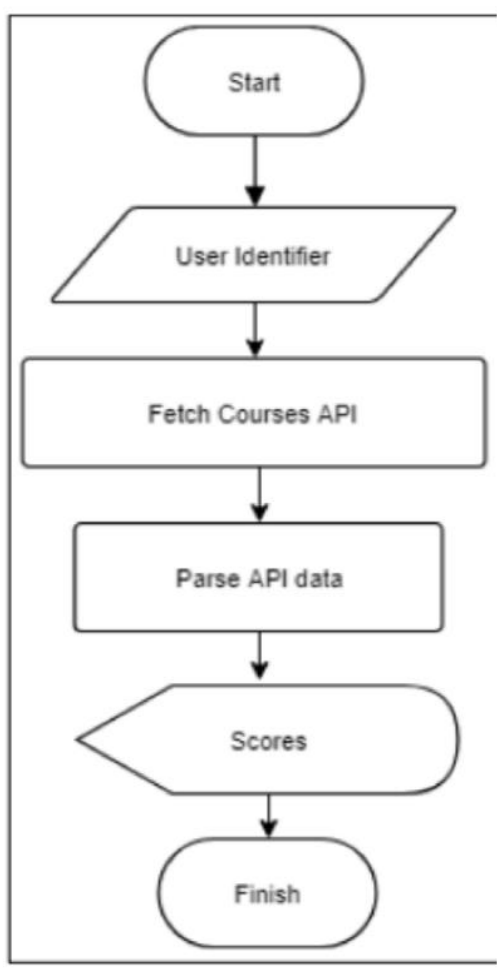

Scores

The image above explains the assessment flow in the LEKAS application. Participants who have carried out evaluation activities can directly see the results they have obtained. In the picture on the side, you can see the trial implementation of the evaluation with a score of 48 , in the upper right corner the time is used to do the evaluation. If students have finished working on 25 questions, students can submit them immediately or wait until the time runs out. When it is finished, students can press the finish button then the score will appear from the evaluation that has been done.

\subsection{The effectiveness of using LEKAS applications in learning activities}

The process of learning economic education activities mostly still uses conventional learning. The use of e-learning is still not used to it. So that students can only learn through books and explanations from lecturers. In today's era, the use of smartphones is increasing and almost all students use them [32]. From the results of the preliminary analysis of the problems faced by students regarding learning motivation, interest 
in learning, and learning outcomes are strongly influenced by the use of technology in the learning process.

After LEKAS application was tested, students filled out a questionnaire and were interviewed by the researcher. The students expressed that they were happy if learning was packaged using technology, especially using smartphones. Students feel they can study the material and access the tests given by the lecturer anytime and anywhere [33]. Today's students cannot be separated by the use of smartphones, they use their devices more for social media and playing games than for studying [34]. Students are easily distracted when a notification comes in when they learn to use their device. It is a negative effect if full learning uses applications on the device [34]. Regarding motivation and interest in learning, students will be more excited when they are given assignments by surfing in cyberspace, exploring their curiosity rather than having to find out in reference books [35]. After implementing the application, they find it easy to repeatedly learn material that is still not understood. Students can adjust to their respective learning styles in learning material. They can also adjust their learning rhythm and speed after this application. Students do not feel worried about missing material because they can read it anytime. Students only have a limited time to be able to focus on reading material, because they will be bored and bored if they read material on their devices for a long time [36]. They will even open other applications that are fun instead of learning continuously.

Students' understanding of the achievement of learning objectives is measured by providing an evaluation in the form of a written test. In this application there is an evaluation feature that can be provided with multiple choice written tests and essays with short answers. Students will do an evaluation according to the design of the lecturer, each question will have time to do it. After finishing working on the evaluation questions, a score will appear to see the extent to which students understand the learning material. The most important thing here is that students realize an improvement in the quality of understanding after studying the material through the LEKAS application. In accordance with the results of research [37], that there is an increase in the productivity of using the application and an increase in interest and motivation to learn after using the LEKAS application. This shows that the use of the LEKAS application is more effective than using conventional learning.

The feature designed on the LEKAS platform is a material feature that contains material with PDF files and embed videos from YouTube. At the implementation stage, the researcher also conducted application testing on students to find out deficiencies that needed to be fixed. The drawback of this application is that it can only be used on certain types of Android-based smartphones, so that when registering students had difficulty entering the application. Students who use iOS-based smartphones are still unable to use this platform as a learning medium. The features offered on this platform are still relatively simple, namely only material in the form of PDFs and embed videos from YouTube. The evaluation compiled is still relatively simple, only in the form of multiple choices and a brief description. The use of short descriptions can only show keywords with correct answers. Students at the beginning of the installation also still experience many problems when registering. So, the next improvement is to allow all types of android to be able to access this platform. 


\section{Conclusion}

Thus, it can be concluded that the LEKAS platform can be implemented well in the research subject, namely 2019 economic education students. This platform can be used easily and flexibly even though its features are still very simple. Material can be entered in the course menu and in PDF and video form making it easier for students to learn the material. After students study the material, students can measure their understanding and mastery by working on evaluation questions which can be in the form of multiple choice and short descriptions and can immediately find out the results directly. The drawback of this platform is that it can only be used on smartphones based on Android. Students are very enthusiastic about technology-based learning innovations, students feel happy with lectures that can be carried out anywhere and anytime. Many improvements and additional features are needed for the perfection of this LEKAS platform. So that the quality of learning can be improved.

This study also concludes that mobile-based learning using the LEKAS application is more effective when compared to conventional learning. Evidenced by an increase in understanding of learning outcomes through the acquisition of scores when doing evaluations. Student responses in using this application are also positive seen with the enthusiasm and intensity of their interactions with this application. This research is limited to economic materials, so the researcher cannot be sure whether this simple feature is suitable for exact learning material. The need for improvements in features and additional features will make this LEKAS application more perfect and useful.

\section{References}

[1] Palandi, J.F, Aminah, S, and Pudyastuti, S.E. (2017). E-Learning Web Application Development for Anti-Corruption Education Using Moodle. Jurnal inovtek polbeng - seri informatika, vol. 2, no. 2, November 2017 ISSN: 2527-9866. https://media.neliti.com/ media/publications/256243-pengembangan-aplikasi-web-e-learning-unt-d0d6ba00.pdf. https://doi.org/10.35314/isi.v2i2.204

[2] Khanghah, M. F and Halili, S.H. (2015). Design and Development of Mobile Learning Application. The Online Journal of Distance Education and e-Learning, April 2015 Volume 3 , Issue 2 .

[3] Alden, J. (2013). Accommodating mobile learning in college programs, Journal of Asynchronous Learning Networks, vol. 17, no. 1, pp. 109-122.

[4] Zydney, J. M. and Z. Warner. (2016). "Mobile apps for science learning: review of research," Computers \& Education, vol. 94, pp. 1-17. https://doi.org/10.1016/j.compedu. $\underline{2015.11 .001}$

[5] Trifonova, A. and M. Ronchetti. (2003). "Where is mobile learning going?" in Proceedings of E-Learn: World Conference on E-Learning in Corporate, Government, Healthcare, and Higher Education, Phoenix, AZ, USA

[6] Elkhateeb,Menna Et all. (2019). Mobile Learning System for Egyptian Higher Education Using Agile-Based Approach. Hindawi Education Research International 2019, Article ID 7531980, 13 pages. https://doi.org/10.1155/2019/7531980

[7] Efendi, Neng Marlina. (2018). Digital-Based Learning Revolution (Use of Digital Animation at Start Up as a Learning Method for Active Learning Students). Habitus: Jurnal Pen- 
didikan, Sosiologi dan Antropologi Vol. 2 No.2 September 2018 p.173-182. https://doi.org/10.20961/habitus.v2i2.28788

[8] Satya, Alfa. (2014). Beginning Android Programming with ADT BUNDLE. Tangerang: Elex Medis Komputindo

[9] Musfah, J. (2011). Teacher Competency Improvement (Through Training and Learning Resources for Theory and Practice). Jakarta: Kencana.

[10] Suartama, I. K, Setyosari. P, Sulthoni, and Ulfa, S. (2020). Development of Ubiquitous Learning Environment Based on Moodle Learning Management System. International Journal of Interactive Mobile Technologies: Vo. 14 No. 14, 2020. Pp 182-204.. https://doi.org/10.3991/ijim.v14i14.11775

[11] AECT. (1977). Definition of Educational Technology. (Translated by PAU at the Open University). Publisher Management PT. Grafindo Persada. Jakarta.

[12] Permendikbud No 21 Tahun 2016 about Process Standards

[13] Sugeng P, Heni R, dan Achmad T. (2013). Mobile Searching for Pekanbaru Tourism Objects Using an Android-Based Location Base Service (LBS). Jurnal. Politeknik Caltex Riau. (Vol $1 \mathrm{hlm} \mathrm{177).} \mathrm{http://www.pdii.lipi.go.id/wp} \mathrm{content/uploads/2014/03/Seminar-}$ Nasional- nfonnatika-_SNlf- 2013

[14] Arif Akbarul Huda. (2013). 24 Smart Hours of Android Programming, ANDI, Yogyakarta.

[15] Mueangpud, A, Khlaisang. J, and Koraneekij. (2019). Mobile Learning Application Design to Promote Youth Financial Management Competency in Thailand. International Journal of Interactive Mobile Technologies: Vol 13 No 12, 2019. https://doi.org/10.3991/ijim. v13i12.11367

[16] Blilat, A., Ibriz, A. (2020). Design and Implementation of P2P Based Mobile App for Collaborative Learning in Higher Education. International Journal of Interactive Mobile Technologies, 14(7): 115-132. https://doi.org/10.3991/ijim.v14i07.13167

[17] Traxler, J. (2005). Defining Mobile Learning. IADIS International Conference Mobile Learning 2005, ISBN: 972-8939-02-7.

[18] Traxler, John. (2009). Learning in a Mobile Age. International Journal of Mobile and Blended Learning. 1(1), 1-12. doi:10.4018/jmbl.2009010101

[19] Volkovitckaia, G., Tikhonova, Y., Kolosova, O. (2020). Educational Experience in the Mobile Learning Environment: Consumer Behaviour Perspective. iJIM vol. 14 (21). https://doi.org/10.3991/ijim.v14i21.18441

[20] Kraleva, R. (2017). Designing an Interface for a Mobile Application Based on Children's Opinion. iJIM Vol. 11 (1). https://doi.org/10.3991/ijim.v11i1.6099

[21] Ismail, I., Azizan, S.T., Gunasegaran, T., (2016). Mobile Learning in Malaysian Universities: Are Students Ready? iJIM Vol 3 (10). https://doi.org/10.3991/ijim.v10i3.5316

[22] Y. Zidoun, F. El arroum, M. Talea, R. (2016). Students' Perception About Mobile Learning in Morocco: Survey Analysis. iJIM Vol. 10 (4). https://doi.org/10.3991 lijim.v10i4.5947

[23] Kattayat , S., Josey, S., Asha J.V. (2017). Mobile Learning Apps in Instruction and Students Achievement. iJIM Vol 11 (1). https://doi.org/10.3991/ijim.v11i1.6420

[24] Al-Hunaiyyan, A., Alhajri, R., Al-Sharhan, S. (2017). Instructors Age and Gender Differences in the Acceptance of Mobile Learning. iJIM Vol 11 (4). https://doi.org/ $\underline{10.3991 / \text { ijim.v11i4.6185 }}$

[25] Yunita, A., Nursechafia, Setiawan,E., Nugroho, H. (2018). The Relationship between Mobile Phone Usage in Classroom and Academic Achievement in College Life. iJIM Vol. 12(8). https://doi.org/10.3991/ijim.v12i8.9530

[26] Al-Hunaiyyan, A. (2017). A New Mobile Learning Model in the Context of Smart Classroom Environment: A Holistic Approach. iJIM Vol. 11 (3). https://doi.org/10.3991/ ijim.v11i3.6186

[27] A.W., Irawan. 2020. Laporan Survei Internet APJII 2019-2020 (Q2). Online: https://www.apjii.or.id/survei 
[28] Drigas, A.S., Paraskevi, A., Attica (2017). Mobile Applications within Education an Overview of Application Paradigms in Specific Categories. iJIM Vol 11 (4). https://doi.org/10.3991/ijim.v11i4.6589

[29] M. Al-Emran, H. Elsherif and K. Shaalan. (2016). Investigating Attitudes Towards The Use Of Mobile Learning In Higher Education. Computers in Human Behavior, 56 (2016), pp. 93-102. https://doi.org/10.1016/j.chb.2015.11.033

[30] Shuib, M., Abdullah, A., Azizan, S.T, Gunasegaran, T., (2015). Designing an Intelligent Mobile Learning Tool for Grammar Learning (i-MoL), iJIM Vol. 9 (1). https://doi. org/10.3991/ijim.v9i1.4238

[31] Musahrain. (2016). Developing Android-Based Mobile Learning as a Media in Teaching English. Proceeding The 2nd International Conference on Teacher Training and Education Sebelas Maret University 307 Vol 2 No 12016 ISSN: 25002 - 4124

[32] H. Crompton and D. Burke. (2018). "The use of mobile learning in higher education: A systematic review," Comput. Educ., vol. 123, pp. 53-64, 2018. https://doi.org/10.1016/ j.compedu.2018.04.007

[33] Lestari, I., Maksum, A., and Kustandi, C. (2019). Mobile Learning Design Models for State University of Jakarta, Indonesia. International Journal of Interactive Mobile Technologies: Vol 13 No 9, 2019. https://doi.org/10.3991/ijim.v13i09.10987

[34] Talib, C.A. et all. (2019). Sakai: A Mobile Learning Platform. International Journal of Interactive Mobile Technologies: Vol 13 No 9, 2019. https://doi.org/10.3991/ijim. v13i11.10800

[35] Miller, H.B., \& Cuevas, J. (2017). Mobile learning and its effects on academic achievement and student motivation in middle grades students. Int. J. Scholarsh. Technol. Enhanc. Learn. 1(2), 91-110.

[36] Aberdour, M. (2013). Moodle for mobile learning. UK: Packt Publishing Ltd.

[37] H. Crompton and D. Burke, (2018). "The use of mobile learning in higher education: A systematic review," Comput. Educ., vol. 123, pp. 53-64, 2018. https://doi.org/10.1016/ j.compedu.2018.04.007

\section{Authors}

Rizza Megasari is a Asisstant Professor at Economic Development Study Program, Universitas Negeri Malang, Indonesia. Email: rizza.megasari.fe@um.ac.id

Agung Haryono is a Associate Professor at at Economic Development Study Program, Universitas Negeri Malang, Indonesia Email: agung.haryono.fe@um.ac.id

Rizky Dwi Putri is a Asisstant Professor at Economic Development Study Program, Universitas Negeri Malang, Indonesia. Email: rizky.dwi.fe@um.ac.id

Lisa Rokhmani is a Asisstant Professor at Economic Development Study Program, Universitas Negeri Malang, Indonesia. Email: lisa.rokhmani.fe@um.ac.id

Ro'ufah Inayati is a Asisstant Professor at Economic Development Study Program, Universitas Negeri Malang, Indonesia. Email: roufah.inayati.fe@um.ac.id

Sri Handayani is a Asisstant Professor at Economic Development Study Program, Universitas Negeri Malang, Indonesia. Email: sri.handayani.fe@um.ac.id

Annisya' is a Asisstant Professor at Economic Development Study Program, Universitas Negeri Malang, Indonesia. Email: annisya.fe@um.ac.id

Article submitted 2021-01-22. Resubmitted 2021-02-27. Final acceptance 2021-02-29. Final version published as submitted by the authors. 